\title{
A Study of the Use of Narratives in Teaching English as a Foreign Language to Young Learners
}

\author{
Mateja Dagarin Fojkar ${ }^{1}$, Janez Skela ${ }^{2} \&$ Pija Kovač ${ }^{3}$ \\ 1 Faculty of Education, University of Ljubljana, Slovenia \\ ${ }^{2}$ Faculty of Arts, University of Ljubljana, Slovenia \\ ${ }^{3}$ Primary school Ljubljana, Slovenia \\ Correspondence: Mateja Dagarin Fojkar, Faculty of Education, University of Ljubljana, Kardeljeva ploscad 16, \\ 1000 Ljubljana, Slovenia. Tel: 386-1-5892-200. E-mail: mateja.dagarin@guest.arnes.si
}

\author{
Received: March 28, 2013 Accepted: April 14, 2013 Online Published: May 8, 2013 \\ doi:10.5539/elt.v6n6p21 URL: http://dx.doi.org/10.5539/elt.v6n6p21
}

\begin{abstract}
The article reports the findings of a survey, conducted among primary school English language teachers in Slovenia, aimed at revealing their attitudes towards the use of narratives in teaching English as a foreign language to children aged from eight to nine years $\left(3^{\text {rd }}\right.$ and $4^{\text {th }}$ grades respectively). The research results show that most teachers use narratives when teaching English, generally once or twice per month, and that teachers who do not use a course book in the classroom employ storytelling or story reading techniques more frequently than teachers who follow a course book in their teaching. Despite the fact that the teachers participating in the study are aware of the importance of narratives in teaching English as a foreign language to young learners, there is still a lot to be done concerning the selection of the narratives, the narrating techniques and the post-narration activities. Proper teacher training for teaching a foreign language to young learners could address most of these issues.
\end{abstract}

Keywords: narratives in foreign language teaching, young language learners, English as a foreign language

\section{Introduction}

In Slovenia, primary education for most children starts after they turn 6 years old and it lasts for 9 years. All pupils start learning a foreign language (FL) formally in the $4^{\text {th }}$ grade of primary school (i.e., at the age of nine). Nevertheless, many schools and kindergartens offer some form of foreign language learning from kindergarten onwards, mostly due to pressure from parents and society to start learning foreign languages earlier. Thus in 2007, English was taught as an extracurricular activity in the first three grades of primary school at $67.7 \%$ of schools and 53.7\% of kindergartens in Slovenia (Kač \& Deutsch 2007: 4, Fras Berro \& Deutsch 2007). However, the forms of teaching vary in quality, length and teacher qualifications. Fortunately, the current chaotic situation will be improved in September 2013, when a foreign language will be gradually introduced as a compulsory subject in the $1^{\text {st }}$ grade of primary school.

Some guidelines exist regarding foreign language teaching methodology in the $4^{\text {th }}$ grade, and teachers can choose from a number of government accredited course books. However, there are not yet many guidelines for teachers in the first three grades of primary school, and teachers are free to choose from a wide variety of materials and course books, many of which also frequently suggest the use of narratives.

\subsection{Theoretical Framework}

Many authors emphasise the importance of using narratives and storytelling in teaching a foreign language, especially to young learners (see Morgan \& Rinvolucri, 1983; Garvie, 1990; Machura, 1994; Wright, 1995, 1997; Kuhiwczak, 1999; Brewster, Ellis \& Girard, 2002; Ellis \& Brewster, 1991, 2002; Waynryb, 2003, Enever, 2006; Láng, 2009; Mourão, 2006, 2011, among others). Daniel (2012: 3) points out that "narrative is the natural way in which humans organise information, and storytelling is the most immediate (and fundamental) means by which that narrative is communicated". Similarly, Egan $(1986,1997)$ identifies a story as one of the most effective tools for communicating new information to young learners. Lugossy (2007: 77), for example, argues that "stories function as schemata on the basis of which we make sense of the world", and by exposing children to stories we provide them opportunities to interpret new information and gradually develop abstract ways of thinking. In 
addition, Ellis and Brewster (2002) stress the importance of developing children's affective as well as linguistic skills through the use of stories, claiming that listening to stories in class is a shared social experience, provoking a shared response of sadness, laughter, excitement and other emotions. Storytelling also provides comprehensible input and is a language learning experience in which the affective filter is low (cf. Krashen 1981). Brewster, Ellis and Girard (2002) have suggested that narrating stories creates ideal language learning conditions, as it provides meaningful context and functions as a springboard for a variety of language learning activities. Cameron (2001) adds that stories represent a holistic approach to language teaching and learning, offering children rich, authentic uses of the foreign language. In their pilot study, Speaker, Taylor \& Kamen (2004) proved that the use of storytelling with young children not only has positive effects but also enhances their grammar, vocabulary, length of utterance and sentence formation.

Despite the abundance of materials and the established positive effects of using narratives in a foreign language classroom, many researchers still stress teachers' resistance to using stories in the classroom. For example, in their report on global practices in teaching English to young learners, Garton, Copland \& Burns (2011: 12) observe that "one very noticeable absentee from the list of frequently used activities is storytelling". In their investigation of 4,696 responses of teachers from 144 countries, only $42 \%$ of the teachers reported telling stories in every lesson or often, while $17 \%$ said they never or rarely read stories. The authors found this fact surprising given the importance of storytelling in the young learner literature.

Similarly, Lugossy (2006) investigated teachers' beliefs regarding the use of narratives in the foreign language classroom and found that narratives were intrinsically motivating for all age groups, including young learners. This finding came as a surprise to many teachers, who doubted the motivational and educational value of stories, thus suggesting the need to raise awareness of the importance of children's literature in teaching languages.

Ellis and Brewster (2002) attribute the resistance to the use of narratives in the young FL classroom to a lack of confidence amongst teachers in their ability to tell stories or read stories aloud. Many teachers have not been trained specifically in teaching young learners and are not acquainted with the methodology for teaching foreign languages to children.

Mattheoudakis et al (2007) raise an interesting issue when they observe that in most European cities the practice of teaching foreign languages in primary school started 20-25 years ago, which means that the current teachers did not have an opportunity to start learning foreign languages at a young age and therefore cannot make reference to their personal learning experiences as young learners. Combined with insufficient training, this results in teachers failing to use an appropriate FL methodology for children, of which narratives is an essential component.

In spite of being recommended as one of the principal teaching tools by many experts dealing with teaching foreign languages to children, narratives are, as the aforementioned studies show, still underused in the foreign language classroom. It is due to this paradoxical fact that we wanted to examine the situation in Slovenia regarding the use of narratives in FL teaching to young learners.

\section{Method}

\section{$2.1 \mathrm{Aim}$}

The main aim of the present study was to investigate the use of narratives in teaching English as a foreign language to eight- and nine-year-old pupils in Slovenia ( $3^{\text {rd }}$ and $4^{\text {th }}$ grades respectively). The study attempted to scrutinise the following issues:

- the frequency of narrative use;

- the relationship between the use of course books and the use of narratives;

- the ratio of reading to telling narratives;

- $\quad$ reasons for using narratives;

- $\quad$ pupils' responses to using narratives;

- the ratio of using authentic to using adapted narratives;

- criteria for selecting books;

- classroom arrangement when using narratives;

- $\quad$ narrating techniques;

- the frequency and the types of activities used after reading or telling narratives. 


\subsection{Method and Participants}

The survey was in the form of a questionnaire consisting of 19 questions (16 closed and 3 open questions). A total of 50 teachers (all female) from 30 Slovenian primary schools responded to the questionnaire, all of whom taught English in the $3^{\text {rd }}$ and/or $4^{\text {th }}$ grades. Of the questionnaires returned, 30 were completed by $4^{\text {th }}$ grade English teachers and 20 by $3^{\text {rd }}$ grade English teachers. In Slovenia, English in the $3^{\text {rd }}$ and $4^{\text {th }}$ grade can be either taught by specialist teachers or primary school teachers who finish an additional programme for teaching English besides other subjects. All pupils officially start learning a foreign language in the $4^{\text {th }}$ grade, but many schools introduce the subject earlier in various forms, mainly as an extracurricular activity. In general, pupils have one to two English lessons per week, depending on the school. The schools that participated in the survey are located in both urban and rural areas.

\section{Study Findings}

Encouragingly, most of the teachers included in the study use narratives in teaching English to the $3^{\text {rd }}$ and $4^{\text {th }}$ grades. All of the $3^{\text {rd }}$ grade teachers confirmed using storytelling or reading stories, and $93 \%$ of the $4^{\text {th }}$ grade teachers use children's literature in their classes. We were pleasantly surprised by this fact, as we do not remember being told or read stories when we were starting to learn English (i.e., approx. 10-20 years ago). At that time language learning was mostly grammar focused and there was an emphasis on accuracy.

Table 1. Frequency of using narratives $(\mathrm{N}=48)$

\begin{tabular}{lll}
\hline & $\mathbf{N}$ & $\mathbf{\%}$ \\
\hline Once per week & 4 & $8.33 \%$ \\
Once or twice per month & 25 & $52 \%$ \\
Less than once per month & 16 & $33.33 \%$ \\
Other & 3 & $6.33 \%$ \\
\hline
\end{tabular}

Table 1 shows that more than half of the respondents (52\%) use children's literature in their lessons once or twice per month. Nevertheless, the proportion of teachers surveyed who use children's literature less than once per month (33.3\% overall) is still very high. Two of the teachers who chose 'other' commented that they use narratives in their lessons only in the second term, when pupils are preparing for the national extensive English reading project, which is a national project involving reading adapted books in English across all levels (mainly primary and secondary school), organised by two major publishing houses in Slovenia. (Note 1) One of the teachers who chose 'other' reported that she used narratives in her $3^{\text {rd }}$ grade three times a week; she teaches in a Montessori school, which has more English lessons per week and uses different teaching methods from public schools, thus accounting for the increased frequency of use.

Table 2. Use of narratives in class in relation to use of a course book $(\mathrm{N}=50)$

\begin{tabular}{lll}
\hline Frequency of using narratives & $\begin{array}{l}\text { Using course book } \\
(\mathbf{N = 3 9 )}\end{array}$ & $\begin{array}{l}\text { Not using course book } \\
\mathbf{( N = 1 1 )}\end{array}$ \\
\hline Three times per week & $0(0 \%)$ & $1(9 \%)$ \\
Once per week & $2(5.12 \%)$ & $2(18 \%)$ \\
Once or twice per month & $18(46.14 \%)$ & $7(64 \%)$ \\
Less than once per month & $15(38.5 \%)$ & $1(9 \%)$ \\
Other & $2(5.12 \%)$ & $0(0 \%)$ \\
Never & $2(5.12 \%)$ & $0(0 \%)$ \\
\hline
\end{tabular}

The data presented in Table 2 show that slightly less than half of the surveyed teachers who reported that they used a course book in their English lessons stated that they used narratives in class once or twice per month, while as many as $38.5 \%$ claimed that they used narratives less than once per month. Two teachers used narratives only in the national extensive English reading project, and two of them never used narratives in their English lessons in the $3^{\text {rd }}$ and $4^{\text {th }}$ grades. In contrast, all of the teachers who did not follow a course book used children's literature in some way, with $64 \%$ of them using narratives at least once or twice per month, two of them using narratives once per week, and one of them even using narratives three times per week. Only $9 \%$ of the teachers not following a course book used children's literature less than once per month. 
Table 3. Ratio of reading to telling narratives $(\mathrm{N}=48)$

\begin{tabular}{lll}
\hline & $\mathbf{N}$ & $\%$ \\
\hline Reading & 25 & $52 \%$ \\
Telling & 10 & $21 \%$ \\
Both equally & 13 & $27 \%$ \\
\hline
\end{tabular}

Table 3 demonstrates that over half of the respondents (52\%) prefer reading a story while only $21 \%$ would rather tell a story, with $27 \%$ of teachers using both methods. Distinguishing further between $3^{\text {rd }}$ and $4^{\text {th }}$ grade teachers reveals that many more $3^{\text {rd }}$ grade teachers $(40 \%)$ than $4^{\text {th }}$ grade teachers $(7 \%)$ prefer telling a story.

Table 4. Reasons for using narratives $(\mathrm{N}=48)$

\begin{tabular}{lll}
\hline & $\mathbf{N}$ & $\mathbf{\%}$ \\
\hline Excellent means of motivation & 32 & $20 \%$ \\
Good source of language & 30 & $19 \%$ \\
Pupils love listening to stories in English & 36 & $22.5 \%$ \\
A good starting point for various activities & 29 & $18 \%$ \\
Relaxed, safe atmosphere & 29 & $18 \%$ \\
Other & 4 & $2.5 \%$ \\
\hline
\end{tabular}

The respondents were allowed to choose more than one response in this question; however, the highest proportion of teachers $(22.5 \%)$ stated that the reason for using narratives in teaching English was their pupils' love of listening to stories. One fifth of the respondents valued the stories' motivational aspect, and $19 \%$ considered stories to be a good source of language.

Table 5. Pupils' responses to using narratives $(\mathrm{N}=48)$

\begin{tabular}{lll}
\hline & $\mathbf{N}$ & $\mathbf{\%}$ \\
\hline Pupils love narratives in English & 40 & $83 \%$ \\
Pupils are bored & 0 & $0 \%$ \\
Their responses vary & 8 & $17 \%$ \\
\hline
\end{tabular}

The results were similar in both age groups, with $83 \%$ of all respondents reporting that their pupils loved listening to stories in English, and only 17\% stating their pupils' responses varied. It is encouraging to see that, according to their teachers, none of the pupils feel bored when narratives are used in class.

Table 6. Ratio of using authentic to using adapted narratives $(\mathrm{N}=48)$

\begin{tabular}{lll}
\hline & $\mathbf{N}$ & $\mathbf{\%}$ \\
\hline Authentic & 14 & $29 \%$ \\
Adapted & 34 & $71 \%$ \\
\hline
\end{tabular}

Table 6 shows that the majority of teachers surveyed (71\%) preferred using adapted stories rather than authentic stories. Distinguishing further between $3^{\text {rd }}$ and $4^{\text {th }}$ grade teachers revealed that $3^{\text {rd }}$ grade teachers used more authentic narratives than $4^{\text {th }}$ grade teachers $(10 \%$ more), even though pupils' language skills are more developed in the $4^{\text {th }}$ grade and they can understand more demanding structures and vocabulary.

Table 7. Criteria for selecting books

\begin{tabular}{lll}
\hline & $\mathbf{N}$ & $\mathbf{\%}$ \\
\hline Books I like & 18 & $19 \%$ \\
Books to my pupils' liking & 31 & $33 \%$ \\
Books allowing for a variety of activities & 21 & $22 \%$ \\
Books related to the topic in the course book & 19 & $20 \%$ \\
Other & 6 & $6 \%$ \\
\hline
\end{tabular}


It is encouraging that the main selection criterion for material is that teachers believe their pupils will like the books, with $33 \%$ of respondents basing their choice on this criterion and only $19 \%$ favouring books they like themselves. The second criterion for $4^{\text {th }}$ grade teachers is that the books are related to the topic of the course book $(26 \%)$, while this is only the fourth criterion amongst $3^{\text {rd }}$ grade teachers $(13 \%)$. This finding is supported by the fact that only $45 \%$ of the $3^{\text {rd }}$ grade teachers surveyed use a course book, and are therefore more flexible in using a variety of books. Teachers who answered 'other' reported that they used books included in the national extensive English reading project.

Table 8. Classroom arrangement when using narratives $(\mathrm{N}=48)$

\begin{tabular}{lll}
\hline & $\mathbf{N}$ & $\mathbf{\%}$ \\
\hline Classroom arrangement unchanged & 6 & $12.5 \%$ \\
Pupils are seated on the floor & 32 & $67 \%$ \\
Desks are arranged in a semicircle & 4 & $8 \%$ \\
Other & 6 & $12.5 \%$ \\
\hline
\end{tabular}

Table 8 shows that the highest proportion of all respondents (67\%) seat their pupils on the floor while telling or reading narratives. However, a rather high percentage of teachers in the survey $(12.5 \%)$ still do not change the classroom arrangement during narrative lessons. These are predominantly $4^{\text {th }}$ grade teachers $(18 \%)$, compared to only $5 \%$ of third grade teachers. Some teachers explained that their classroom arrangement depends on the objectives of a particular lesson, i.e., pupils remain seated in their usual places if they need to take notes, colour something or do other tasks related to the narrative. One teacher answered that she usually did the storytelling in the school gym or hall, where her pupils could be seated on the stairs.

Table 9. Use of narrating techniques

\begin{tabular}{lll}
\hline & $\mathbf{N}$ & $\mathbf{\%}$ \\
\hline Show illustrations & 47 & $31 \%$ \\
Use mime & 37 & $24.5 \%$ \\
Use different voices/vary voice & 47 & $31 \%$ \\
Use puppets/requisites & 18 & $12 \%$ \\
None & 2 & $1.5 \%$ \\
\hline
\end{tabular}

The study reveals that the techniques used by the majority of both $3^{\text {rd }}$ and $4^{\text {th }}$ grade teachers are the use of illustrations and the use of voice variations. A high proportion of teachers stated that they used mime when telling or reading narratives. However, only a small number of teachers used puppets or other realia in narrations, and a few $4^{\text {th }}$ grade teachers admitted not using any techniques at all in narrating stories.

Table 10. The frequency of using post-narration activities $(\mathrm{N}=48)$

\begin{tabular}{lll}
\hline & $\mathbf{N}$ & $\mathbf{\%}$ \\
\hline Always & 30 & $62.5 \%$ \\
Sometimes & 14 & $29 \%$ \\
Rarely & 3 & $6.5 \%$ \\
Never & 1 & $2 \%$ \\
\hline
\end{tabular}

The results show that the majority of the teachers involved in the study always, or at least sometimes, used activities after narrating a story. Narrations are thus used primarily for educational purposes, and not as pleasure reading or storytelling.

Table 11. Types of post-narration activities

\begin{tabular}{lll}
\hline & $\mathbf{N}$ & $\mathbf{\%}$ \\
\hline Discussion & 35 & $27 \%$ \\
Drawing & 33 & $25.5 \%$ \\
Role play & 37 & $29 \%$ \\
Vocabulary and grammar activities & 18 & $14 \%$ \\
Other & 6 & $4.5 \%$ \\
\hline
\end{tabular}


It is positive to note that role play is one of the most frequently used activities after reading or telling narratives, followed in second place by discussion about the narrative. Drawing a picture connected to the narrative is the third most often used follow-up activity. Vocabulary and grammar activities are frequently used for reinforcing language structures and phrases.

\section{Discussion}

The main aim of the research study was to explore the use of narratives in teaching English to $3^{\text {rd }}$ and $4^{\text {th }}$ grade primary school pupils in Slovenia. The research was conducted with the aid of a questionnaire. Firstly, the results show that most of the teachers surveyed use narratives when teaching English in the $3^{\text {rd }}$ and $4^{\text {th }}$ grades, generally once or twice per month. This implies that storytelling and reading are quite common techniques used in foreign language teaching to young learners in Slovenian primary schools. However, there are still quite a high number of teachers who use these techniques infrequently, i.e., less than once per month. The data clearly show that teachers not using a course book tend to use narratives more often in their teaching of English to young learners, presumably because they prepare their own materials and narratives represent an indispensable resource for language learning.

The study also reveals that teachers prefer reading rather than telling narratives when teaching English to $3^{\text {rd }}$ and $4^{\text {th }}$ grade pupils. One of the most likely reasons for this is that storytelling requires more preparation related to the story itself, as well as demanding good storytelling techniques and performing skills, while reading offers verbal (e.g., the text of the story) and non-verbal (e.g., illustrations) support to both teachers and learners. Nevertheless, telling a story should be used more often in the young learner classroom, as it offers a shared social experience and creates a relaxed classroom atmosphere. Furthermore, it is easier to verify pupils' understanding of a story while telling the story, and it is also easier to adapt the language or speed of delivery, as has already been established by many authors, e.g., Brewster \& Ellis, 2002 and Wright, 1995, 1997 among others.

It comes as no surprise that the majority of pupils like listening to narratives, and therein lies the main reason for teachers using them. The teachers in the study stated that narratives are also a good source of language and a springboard for follow-up activities, as well as generating a relaxed and safe learning environment. Having pupils seated on the floor, in the form of a semicircle, further contributes to the pleasant atmosphere in the classroom.

The main criterion for the selection of books is the fact that pupils like them, while most teachers in the survey stated that they preferred adapted books to authentic material. The principal reason for selecting adapted rather than authentic books might again be the additional work for teachers if authentic stories are selected. With authentic stories, teachers commonly need to adapt the language, create their own accompanying activities and similar, whereas adapted stories can often be used in the classroom without additional preparation, as the language is already adapted to the learners' language level and the books often include follow-up activities. Nevertheless, the authors believe that authentic stories also expose young learners to real language and offer them a glimpse into another culture, and should therefore be used in the classroom more regularly.

The study also found that teachers use illustrations, mime and voice variations during narration to help pupils understand the story. Interestingly, similar results were discovered by Mattheoudakis et al (2007) in an experimental study on the implementation of a story-based module, which found that the majority of Czech, Hungarian and Greek student teachers used voice variations and visual aids when telling stories. However, as with teachers from these countries, few teachers in Slovenia use puppets or other realia in narrations, which indicates that they should be more aware of the use of realia as one of the essential tools in FL teaching to children.

The teachers in the present survey almost always use follow-up activities to either verify pupils' understanding of the narratives (discussion, drawing) or develop their vocabulary and grammar. Role play, the most frequently occurring post-narration activity, is especially appropriate for younger learners, since it incorporates movement, speaking with chunks of language, and occasionally also the use of realia. Drawing a picture connected to the narrative as a follow-up activity might not be linguistically challenging for pupils or might lack the linguistic aim, as well as being time consuming. The time used for drawing can be more effectively used for other, more productive language learning activities. We therefore suggest that this activity be used selectively in the classroom, or that it be accompanied with a linguistic aim.

Although the results originate from a limited dataset, they demonstrate that the teachers participating in the study are aware of the importance of narratives in teaching English as a foreign language to young learners. There is, however, still a lot to be done regarding the selection of the narratives, narrating techniques and post-narration 
activities. Proper teacher training for teaching a foreign language to young learners could address most of these issues.

Finally, we believe there is still a great deal of research to be done regarding using narratives in teaching a foreign language. In future, a larger number of respondents would provide a more accurate picture of the use of narratives in primary schools, and teacher questionnaires supported with classroom observation and pupil interviews would offer a valid overview of the current state of the use of narratives in Slovenia and elsewhere.

\section{References}

Brewster, J., Ellis, G., \& Girard, D. (2002). The primary English teacher's guide (2nd ed.). London: Penguin Books.

Cameron, L. (2001). Teaching languages to young learners. Cambridge: Cambridge University Press. http://dx.doi.org/10.1017/CBO9780511733109

Daniel, A. K. (2012). Storytelling across the primary curriculum. London: Routledge.

Egan, K. (1986). Teaching as story telling: an alternative approach to teaching and curriculum in the elementary school. Chicago: University of Chicago Press.

Egan, K. (1997). The educated mind: How cognitive tools shape our understanding. Chicago: University of Chicago Press. http://dx.doi.org/10.7208/chicago/9780226190402.001.0001

Ellis, G., \& Brewster, J. (1991). The storytelling handbook for primary teachers. London: Penguin.

Ellis, G., \& Brewster, J. (2002). Tell it again! The new storytelling handbook for primary teachers. Harlow: Pearson Education Limited.

Enever, J. (2006). The use of picture books in the development of critical visual and written literacy in English as a foreign language. In J. Enever, \& G. Schmid-Schonbein (Eds.), Picture books and young learners of English (pp. 59-70). Munich, Germany: Langenscheidt.

Fras Berro, F., \& Deutsch, T. (2007). Tuji jeziki v vrtcih (Foreign languages in kindergartens). Ljubljana: National Education Institute.

Garton, S., Copland, F., \& Burns, A. (2011). Investigating global practices in teaching English to young learners. UK: British Council.

Garvie, E. (1990). Story as vehicle: Teaching English to young children. Clevedon: Multilingual Matters.

Kač, L., \& Deutsch, T. (2007). Pouk tujih jezikov v osnovnih šolah. Poročilo anketne raziskave (Foreign languages in primary schools: A report of a survey). Ljubljana: National Education Institute.

Krashen, S. (1981). Second language acquisition and second language learning. Oxford: Pergamon.

Kuhiwczak, P. (1999). Enchantment in the classroom: Children's literature as a teaching aid. In S. Rixon (Ed.), Young learners of English: Some research perspectives (pp. 43-54). Harlow: Longman.

Láng, K. (2009). The role of storybooks in teaching English to young learners. Practice and Theory in Systems of Education, 4(1), 47-54.

Lugossy, R. (2006). Shaping teachers' beliefs through narratives. In M. Nikolov, \& J. Horváth (Eds.), UPRT 2006: Empirical studies in English applied linguistics (pp. 313-336). Pécs: Lingua franca Csoport.

Lugossy, R. (2007). Authentic picture books in the lives of young EFL learners and their teachers. In M. Nikolov, J. Mihaljević Djigunović, G. Lundberg, T. Flanagan, \& M. Matheoudakis (Eds.), Teaching modern languages to young learners: Teachers, curricula and materials (pp. 77-89). Strasbourg: Council of Europe.

Machura, L. (1994). Using literature in language teaching. In C. Brumfit, J. Moon, \& R. Tongue (Eds.), Teaching English to Children: From Practice to Principle (pp. 67-81). London: Nelson.

Mattheoudakis, M., Dvorakova, K., \& Láng, K. (2007). Story-based language teaching: An experimental study on the implementation of a module in three European countries. In M. Nikolov, J. Mihaljević Djigunović, G. Lundberg, T. Flanagan, \& M. Matheoudakis (Eds.), Teaching modern languages to young learners: Teachers, curricula and materials (pp. 59-76). Strasbourg: Council of Europe.

Morgan, J., \& Rinvolucri, M. (1983). Once upon a time: Using stories in the language classroom. Cambridge: Cambridge University Press.

Mourão, S. (2006). Understanding and sharing English storybook borrowing in Portuguese pre-schools. In J. 
Enever, \& G. Schmid-Schonbein (Eds.), Picture books and young learners of English (pp. 49-58). Munich, Germany: Langenscheidt.

Mourão, S. (2011). Picturebooks are for children and teenagers. In J. Bland (Ed.), IATEFL Young Learner and Teenager Special Interest Group Publication, 2011(1), 5-11.

Speaker, M. K., Taylor, D., \& Kamen, R. (2004). Storytelling: Enhancing language acquisition in young children. Education, 125(1), 3-14.

Wajnryb, R. (2003). Stories: Narrative activities for the language classroom. New York: Cambridge University Press.

Wright, A. (1995). Storytelling with Children. Oxford: OUP.

Wright, A. (1997). Creating Stories with Children. Oxford: OUP.

\section{Notes}

Note 1 . In the 2011/2012 school year, more than 50,000 primary and secondary school pupils participated in the national extensive English reading project organised by one publishing house (data provided by the publishing house). 